\title{
Establishment of Urochloa brizantha cultivars intercropped with different cereal grains
}

\author{
Estabelecimento de cvs de Urochloa brizantha em resposta a \\ diferentes sistemas de consórcio com cereais
}

\author{
Durval Nolasco das Neves Neto ${ }^{1 *}$; Antonio Clementino dos Santos ${ }^{2}$; \\ Luciano Fernandes Sousa ${ }^{2}$; Perlon Maia dos Santos ${ }^{3}$; Aridouglas dos Santos Araujo \\ Nayara Martins Alencar ${ }^{4}$
}

\begin{abstract}
Crop-livestock integration is an alternative method of rehabilitating degraded pastures. The goal of the present study was to evaluate the initial responses of morphostructural characteristics of two different Urochloa brizantha cultivars grown in monocropping or intercropping systems over two agricultural years. $U$. brizantha cultivars Marandu and Piatã were grown as monocrops or intercropped with corn or sorghum. A randomized block experimental design with a triple factorial scheme, two additional treatments $(2 \times 2 \times 2+2)$ and four replicates was used. The following factors were tested: two $U$. brizantha cultivars (Marandu or Piatã), two intercropping combinations (with corn or sorghum), and two agricultural years (2010/2011 and 2011/2012). An additional treatment included U. brizantha cultivars grown as monocrops. The morphogenic and structural characteristics and forage gross production rates were evaluated in the different cropping systems. Intercropping with grain crops had a negative effect on the initial productivity of $U$. brizantha, and areas with intercropping presented higher tiller density, lower rates of leaf emergence and elongation and lower forage gross production rates relative to the monocropping systems. However, intercropping is a viable alternative to conventional monocropping systems, which was indicated by the land equivalent ratio.
\end{abstract}

Key words: Leaf elongation, morphological composition, intercropping, crop-livestock integration, pasture renewal

\section{Resumo}

O sistema de integração lavoura-pecuária surge como alternativa quando se busca recuperar áreas de pastagens degradadas. Objetivou-se avaliar as respostas iniciais das características morfo-estruturais de cultivares de Urochloa brizantha estabelecidas mediante sistema convencional e integração lavourapecuária em dois anos agrícolas. Os tratamentos foram constituídos pela formação do capim-Marandu e Piatã convencionalmente e via integração com milho ou sorgo. O delineamento experimental foi em blocos casualizados, em esquema fatorial triplo com dois tratamentos adicionais $(2 \times 2 \times 2+2)$,

${ }^{1}$ Prof. Dr., Dept ${ }^{\circ}$ de Ciências Humanas e Exata, Instituto Tocantinense Presidente Antônio Carlos, ITPAC, Araguaína, Tocantins, Brasil. E-mail: durval.nolasco@gmail.com

2 Profs. Drs., Programa de Pós-Graduação em Ciência Animal Tropical, Universidade Federal do Tocantins, UFT, Araguaína, Tocantins, Brasil. E-mail: clementino@mail.uft.edu.br; luciano.sousa@mail.uft.edu.br

3 Prof. Dr., Dept ${ }^{\circ}$ de Zootecnia, Universidade Federal Rural da Amazônia, Parauapebas, PA, Brasil. E-mail: perllon_zoo@yahoo. com.br

${ }^{4}$ Discentes do Curso de Doutorado, Programa de Pós-Graduação em Ciência Animal Tropical, UFT, Araguaína, Tocantins, Brasil. E-mail: aridouglas_araujo@hotmail.com; nayara_m1@hotmail.com

* Author for correspondence 
sendo duas cultivares (Marandu ou Piatã); dois métodos de integração (milho ou sorgo); dois anos agrícolas (2010/2011 e 2011/2012); e os tratamentos adicionais pastagens de U. brizantha formadas convencionalmente, com quatro repetições. Foram avaliadas as características morfogênicas, estruturais e a taxa de produção bruta de forragem dos capins nos diferentes sistemas de plantio. A integração de gramíneas forrageiras tropicais com culturas graníferas proporcionou impactos negativos na produtividade inicial das cultivas de $U$. brizantha. As áreas formadas mediante os sistemas integrados promoveram maiores densidades de perfilhos, porém menores taxas de aparecimento e alongamento foliares, além de menor taxa de produção bruta de forragem em relação ao sistema de formação convencional. No entanto, os sistemas integrados são alternativas viáveis em relação ao sistema convencional, visto pelos resultados do índice de equivalência de área.

Palavras-chave: Alongamento foliar, composição morfológica, cultivo integrado, integração lavourapecuária, renovação de pastagem

\section{Introduction}

The distribution of beef cattle production has been changing throughout Brazil primarily because of crop cultivation, especially sugarcane, corn and soya. An analysis of the dynamics of land-cover and land-use in the state of Tocantins shows that the distribution of cattle has reached new production borders. Changes in the natural land cover of this state primarily include the conversion of savannah areas to agriculture land and cattle pasture, with a $12.2 \%$ conversion observed since 1990 (SEPLAN/ DZE, 2012).

This increased land use for cattle raising occurred without properly considering production sustainability, which is shown in estimates disclosed by the government of Tocantins that indicate the presence of degradation in approximately $75 \%$ of the pastures within the state (MOURÃO, 2012). This degradation is primarily caused by inappropriate grazing practices, low natural soil fertility in this region and insufficient nutrient replacement (DIAS FILHO, 2011).

The most viable alternative to reducing degradation and/or rehabilitating pastures is the use of production systems that allow for the intensive use of the available areas, resources and inputs (BALBINOT JÚNIOR et al., 2009). Landuse management systems, such as crop-livestock integration, no tillage cultivation or agroforestry, may help rehabilitate pastures because these systems are designed for continuous land use and promote improved soil fertility over time (FRANZLUEBBERS, 2007; MACEDO, 2009).

Among the types of crop-livestock integration used in Brazil, the intercropping of tropical forage species such as Urochloa brizantha with crops such as corn, millet, sorghum, soya and rice is highlighted (SILVA et al., 2008). In most studies found in the literature, similar productivity is observed in grain crops grown in crop-livestock integration systems relative to that of conventional systems, supporting the economic viability of these systems (PARIZ et al., 2011; RICHART et al., 2010).

Limited information is available on the morphostructural changes of forage plants in the Amazon because these plants present different morphogenic rhythms depending on the type of management adopted, season of the year and development characteristics of the species (PACIULLO et al., 2008).

Understanding the adaptive mechanisms and morphological and physiological changes of grasses is essential for the efficient management and continuity of pastures (LARA; PEDREIRA, 2011). To provide support to crop-livestock integration systems, the goal of the present study was to evaluate the initial morphogenic and structural responses of two cultivars of $U$. brizantha (Syn. Brachiaria 
brizantha) intercropped with corn or sorghum over two agricultural years.

\section{Materials and Methods}

This study was performed at the School of Veterinary Medicine and Zootechnics of the Federal University of Tocantins (Escola de Medicina Veterinária and Zootecnia da Universidade Federal do Tocantins - UFT), Araguaína, Tocantins (TO) (07'12'28' S and 48'12'26" W). The natural vegetation is characterized as an Amazon Forest-
Cerrado ecotone. The average altitude is $240 \mathrm{~m}$, and the climate is classified as Aw according to the Köppen climate classification, which indicates a tropical climate, wet summer, well-defined dry and wet seasons and average annual rainfall of $1800 \mathrm{~mm}$. The study site was previously fallow for two and a half years, and creeping plants were the predominant vegetation. The environmental variables were measured once a month during the experimental period (Table 1) at the Agrometeorological Station located at the UFT, Araguaína, TO, at approximately $100 \mathrm{~m}$ from the experimental site.

Table 1. Monthly averages of the maximum, minimum and medium temperatures, sunlight and rainfall levels and cycles during the experimental period (Araguaína, TO; 2013).

\begin{tabular}{|c|c|c|c|c|c|c|c|}
\hline \multirow{2}{*}{ Treatment year } & \multirow{2}{*}{ Cycle } & \multirow{2}{*}{$\begin{array}{c}\text { Month/ } \\
\text { Year }\end{array}$} & $\begin{array}{c}\text { Maximum } \\
\text { Temp. }\end{array}$ & $\begin{array}{l}\text { Minimum } \\
\text { Temp. }\end{array}$ & $\begin{array}{c}\text { Medium } \\
\text { Temp. }\end{array}$ & Sunlight & Rainfall \\
\hline & & & $\left({ }^{\circ} \mathrm{C}\right)$ & $\left({ }^{\circ} \mathrm{C}\right)$ & $\left({ }^{\circ} \mathrm{C}\right)$ & (Hours) & $(\mathrm{mm})$ \\
\hline \multirow{2}{*}{ Year I } & I & $5 / 2011$ & 31.8 & 21.1 & 25.6 & 191.8 & 93.4 \\
\hline & II & $12 / 2011$ & 30.7 & 21.2 & 25.5 & 131.4 & 110.9 \\
\hline Average \pm sd & & & $31.2 \pm 0.8$ & $21.1 \pm 0.07$ & $25.5 \pm 0.07$ & $161.6 \pm 42.7$ & $102.1 \pm 12.4$ \\
\hline \multirow{2}{*}{ Year II } & I & $3 / 2012$ & 31.2 & 20.8 & 25.1 & 144 & 170.1 \\
\hline & II & $4 / 2012$ & 31.9 & 20.7 & 25.7 & 163.1 & 42.2 \\
\hline Average \pm sd & & & $31.5 \pm 0.5$ & $20.7 \pm 0.07$ & $25.4 \pm 0.4$ & $153.5 \pm 13.5$ & $106.1 \pm 90.4$ \\
\hline
\end{tabular}

(Year I) Marandu cv. grown under monocropping; Piatã cv. grown under monocropping; Marandu cv. grown under intercropping with corn; Marandu cv. in grown under intercropping with sorghum; Piatã cv. grown under intercropping with corn; Piatã cv. grown under intercropping with sorghum; (Year II) Marandu cv. grown under intercropping with corn; Marandu cv. grown under intercropping with sorghum; Piatã cv. grown under intercropping with corn; and Piatã cv. grown under intercropping with sorghum. $\mathrm{sd}=$ standard deviation.

The soil had a sandy texture and was classified as Ortic Quartzarenic Neosol (EMBRAPA, 2013). Soil samples were collected from the 0-20 $\mathrm{cm}$ soil layer and analyzed at the Soil Laboratory of the Zootechnics/PGCAT/UFT (EMBRAPA, 2009). The soil analysis determined the following characteristics: $\mathrm{pH} 4.3\left(\mathrm{CaCl}_{2}\right) ; 1.14 \mathrm{mg} \mathrm{dm}^{-3}$
P-Mehlich-1; $2.0 \mathrm{mg} \mathrm{dm}^{-3} \mathrm{~K} ; 1.24 \mathrm{cmol}_{\mathrm{c}} \mathrm{dm}^{-3}$ $\mathrm{Ca} ; 0.47 \mathrm{cmol}_{\mathrm{c}} \mathrm{dm}^{-3} \mathrm{Mg} ; 0.19 \mathrm{cmol}_{\mathrm{c}} \mathrm{dm}^{-3} \mathrm{Al} ; 3.82$ $\mathrm{cmol}_{\mathrm{c}} \mathrm{dm}^{-3} \mathrm{H}+\mathrm{Al} ; 15.97 \mathrm{~g} \mathrm{dm}^{-3}$ organic matter; $1.72 \mathrm{cmol}_{\mathrm{c}} \mathrm{dm}^{-3}$ sum of bases; $5.54 \mathrm{cmol}_{\mathrm{c}} \mathrm{dm}^{-3}$ $\mathrm{CEC}_{\mathrm{pH} 7.0} ; 1.91 \mathrm{cmol}_{\mathrm{c}} \mathrm{dm}^{-3} \mathrm{CEC}_{\mathrm{Ef}} ; 30.99 \%$ base saturation; and $11.27 \%$ aluminum saturation. Following the characterization, the soil acidity 
was corrected through the application of 1.5 tons $\mathrm{ha}^{-1}$ limestone $(88 \%$ total neutralizing power (TNP), $30 \% \mathrm{CaO}$ and $18 \% \mathrm{MgO}$ ), which was plowed and harrowed.

A randomized block experimental design with a triple factorial scheme, two additional treatments $(2 \times 2 \times 2+2)$ and four replicates was used and analyzed according to Yassin et al. (2002). The following factors were tested: two cultivars of $U$. brizantha (Marandu or Piatã), two types of intercrops (corn or sorghum) and two agricultural years (2010/2011 and 2011/2012). Additional treatments consisted of $U$. brizantha cv. Marandu and Piatã grown in a monocropping system. $U$. brizantha cv. Marandu and Piatã monocropping was performed in $225 \mathrm{~m}^{2}$ plots $(15 \mathrm{~m} \mathrm{x} 15 \mathrm{~m})$, and intercropping was performed in $56.25 \mathrm{~m}^{2}$ sub-plots (7.5 m x $7.5 \mathrm{~m})$.

Pastures grown in monocropping or intercropping systems during the 2010/2011 agricultural year retained $U$. brizantha cv. Marandu or Piatã in $2011 / 2012$. In the $2011 / 1012$ agricultural year, the intercropping systems were established in areas previously occupied with forage cereals grown in monocropping systems during the 2010/2011 agricultural year.

$U$. brizantha grown as a monocrop was sown by broadcasting. The forage cereals included the corn variety Robusto, which has high productivity, wide adaptations, a precocious cycle and a $2.60 \mathrm{~m}$ average height and is designed for producers of all technological levels, and sorghum hybrid BRS 610 , which is a forage hybrid that is tall with a dry stem, semi-open panicle, red grain and semihard endosperm without tannin. Forage cereals were planted manually in 5-cm-deep furrows with $0.80 \mathrm{~m}$ spacing between rows, and the plant density was 5 to 9 plants per linear meter, for a total of 62,500 and 112,500 plants $\mathrm{ha}^{-1}$ for corn and sorghum, respectively. For the intercropping systems, $U$. brizantha cultivars were planted 21 days after sowing the grain crops. Double lines were used for brachiaria, with $30 \mathrm{~cm}$ spacing from the annual crop and $20 \mathrm{~cm}$ spacing between rows of the forage grass.

Two fertilizations were performed: formation and top dressing (Table 2). Urea was applied as a nitrogen source, single superphosphate was applied as the $\mathrm{P}_{2} \mathrm{O}_{5}$ source, and potassium chloride was applied as the $\mathrm{K}_{2} \mathrm{O}$ source. The different fertilizers were not mixed for subsequent fertilization. In the monocropping system, the phosphate, nitrogen and potassium fertilizers were applied homogeneously to the entire plot by broadcasting. In the intercropping systems, nitrogen and potassium were applied to the rows of the annual crops (corn and sorghum). 
Table 2. Chronogram of planting and fertilization $\left(\mathrm{kg} \mathrm{ha}^{-1}\right)$ in the different cropping systems and for agricultural years (Araguaína, TO; 2013).

\begin{tabular}{|c|c|c|c|c|c|c|c|}
\hline \multirow[b]{3}{*}{ Treatment } & \multirow{3}{*}{$\begin{array}{c}\text { Planting } \\
\text { Date }\end{array}$} & \multicolumn{6}{|c|}{ Fertilization } \\
\hline & & \multicolumn{2}{|l|}{$\mathbf{N}$} & \multicolumn{2}{|c|}{$\mathbf{P}_{2} \mathrm{O}_{5}$} & \multicolumn{2}{|l|}{$\mathbf{K}_{2} \mathbf{O}$} \\
\hline & & Date & Qt. & Date & Qt. & Date & Qt. \\
\hline P1 & $22 / 01 / 11$ & $24 / 02 ; 05 / 05 / 11$ & 100 & $20 / 01 / 11$ & 100 & $20 / 01 ; 30 / 04 / 11$ & 100 \\
\hline P1 - G1 & $21 / 01 / 11$ & $\begin{array}{c}04 / 02 ; 20 / 02 \\
29 / 03 / 11\end{array}$ & 120 & $20 / 01 / 11$ & 100 & $\begin{array}{c}20 / 01 ; 19 / 02 \\
30 / 03 / 11\end{array}$ & 120 \\
\hline P1 - G2 & $21 / 01 / 11$ & $\begin{array}{c}04 / 02 ; 20 / 02 \\
29 / 03 / 11\end{array}$ & 120 & $20 / 01 / 11$ & 100 & $\begin{array}{c}20 / 01 ; 19 / 02 \\
30 / 03 / 11\end{array}$ & 120 \\
\hline $\mathbf{P 2}$ & $22 / 01 / 11$ & $24 / 02 ; 05 / 05 / 11$ & 100 & $20 / 01 / 11$ & 100 & $20 / 01 ; 30 / 04 / 11$ & 100 \\
\hline P2 - G1 & $23 / 01 / 11$ & $\begin{array}{c}04 / 02 ; 20 / 02 \\
29 / 03 / 11\end{array}$ & 120 & $20 / 01 / 11$ & 100 & $\begin{array}{c}20 / 01 ; 19 / 02 \\
30 / 03 / 11\end{array}$ & 120 \\
\hline P2 - G2 & $23 / 01 / 11$ & $\begin{array}{c}04 / 02 ; 20 / 02 \\
29 / 03 / 11\end{array}$ & 120 & $20 / 01 / 11$ & 100 & $\begin{array}{c}20 / 01 ; 19 / 02 \\
30 / 03 / 11\end{array}$ & 120 \\
\hline P1 - G1 II & $05 / 12 / 11$ & $\begin{array}{c}20 / 12 / 11 ; 04 / 01 \\
16 / 02 / 12\end{array}$ & 120 & $01 / 12 / 11$ & 100 & $\begin{array}{c}04 / 12 / 11 ; 03 / 01 \\
15 / 02 / 12\end{array}$ & 120 \\
\hline P1 - G2 II & $05 / 12 / 11$ & $\begin{array}{c}20 / 12 / 11 ; 04 / 01 \\
16 / 02 / 12\end{array}$ & 120 & $01 / 12 / 11$ & 100 & $\begin{array}{c}04 / 12 / 11 ; 03 / 01 \\
15 / 02 / 12\end{array}$ & 120 \\
\hline P2 - G1 II & $02 / 12 / 11$ & $\begin{array}{c}20 / 12 / 11 ; 04 / 01 \\
16 / 02 / 12\end{array}$ & 120 & $01 / 12 / 11$ & 100 & $\begin{array}{c}04 / 12 / 11 ; 03 / 01 \\
15 / 02 / 12\end{array}$ & 120 \\
\hline P2 - G2 II & $02 / 12 / 11$ & $\begin{array}{c}20 / 12 / 11 ; 04 / 01 \\
16 / 02 / 12\end{array}$ & 120 & $01 / 12 / 11$ & 100 & $\begin{array}{c}04 / 12 / 11 ; 03 / 01 \\
15 / 02 / 12\end{array}$ & 120 \\
\hline
\end{tabular}

Date ending in (11): 2010/2011 agricultural year; Date ending in (12): 2011/2012 agricultural year; (P1) Marandu cv. grown under monocropping; (P1 - G1) Marandu cv. grown under intercropping with corn during the 2010/2011 agricultural year; (P1 - G2) Marandu cv. grown under intercropping with sorghum during the 2010/2011 agricultural year; (P2) Piatã cv. grown under monocropping; (P2 - G1) Piatã cv. grown under intercropping with corn during the 2010/2011 agricultural year; (P2 - G2) Piatã cv. grown under intercropping with sorghum during the 2010/2011 agricultural year; (P1 - G1 II) Marandu cv. grown under intercropping with corn during the 2011/2012 agricultural year; (P1 - G2 II) Marandu cv. grown under intercropping with sorghum during the 2011/2012 agricultural year; (P2 - G1 II) Piatã cv. grown under intercropping with corn during the 2011/2012 agricultural year; and (P2 - G2 II) Piatã cv. grown under intercropping with sorghum during the 2011/2012 agricultural year; Qt = quantity of fertilizer $\left(\mathrm{kg} \mathrm{ha}^{-1}\right)$.

Pasture formation was evaluated according to the morphogenic and structural characteristics of Marandu and Piatã cultivars during the first two cycles following the removal of the annual crops from the intercropping system in both agricultural years. Corn plants were harvested when the milk line was at $50 \%$ of the grain, and sorghum plants were harvested when the grains were at the soft-doughfloury stage; corn and sorghum harvesting occurred at 84 and 88 days after planting, respectively, for the first agricultural year, and at 85 and 91 days, respectively, after planting for the 2011/2012 agricultural year.

The morphogenic characteristics were monitored using the method of marked tillers, which monitors leaf emergence, elongation and senescence and stem elongation. Approximately four days following the harvest, eight representative and well-distributed tillers were selected in each plot, marked and then cut $20 \mathrm{~cm}$ from the soil. The morphological characteristics were assessed weekly until the end of the 28-day cycle. The data obtained were used 
to estimate leaf emergence (LEM), leaf elongation (LE), stem elongation (SE) and leaf senescence (LS) rates, phyllochron length, leaf lifespan (LLS), number of alive (NAL) and dead (NDL) leaves per tiller, average leaf length (ALL) and sheath length (SL) (DIFANTE et al., 2011; LARA; PEDREIRA, 2011; PACIULLO et al., 2008).

The pre-cut height of the forage grass canopy was determined at the end of the 28-day period and determined from 25 random measurements for each plot using a ruler. This parameter was used to select three points for the tiller counts, which were performed using a $0.15 \mathrm{~m}^{2}$ quadrat.

Samples of emerging leaves, fully expanded leaves and stems were harvested at the end of each cycle, and their lengths were measured. The samples were placed in an oven at $55^{\circ} \mathrm{C}$ and dried to a constant weight, and their weight was used to determine the gravimetric factors, such as the conversion factor between the length and dry weight (ALEXANDRINO et al., 2011; PACIULLO et al., 2008). Morphogenic data, tiller density (TD), and gravimetric factors were used to estimate the forage gross production rate (FGPR) (ALEXANDRINO et al., 2011).

The land equivalent ratio (LER) was calculated according to the following equation: $\mathrm{LER}=(\mathrm{Cc} /$ $\mathrm{Mc})+(\mathrm{Cf} / \mathrm{Mf})$, where $\mathrm{Cc}$ represents the intercropping production of forage cereal $\left(\mathrm{kg} \mathrm{DW} \mathrm{ha}{ }^{-1}\right)$, Mc represents the monocropping production of forage cereal (kg DW ha-1), Cf represents the intercropping production of forage grass $\left(\mathrm{kg} \mathrm{DW} \mathrm{ha} \mathrm{g}^{-1}\right)$, and $\mathrm{Mf}$ represents the monocropping production of forage grass (kg DW ha ${ }^{-1}$ ) (VIEIRA, 1984).
The obtained data were subjected to a descriptive statistical analysis of its characteristics and tested for normality. An analysis of variance (ANOVA) was performed, and when significant differences were observed, an $\mathrm{F}$ test was performed for the main effects and interactions at $\mathrm{P}<0.05$. For the additional treatments, significant differences between treatments were tested using Dunnett's test at $\mathrm{P}<0.05$.

\section{Results and Discussion}

Significant differences in the morphogenic and structural parameters of the pasture areas were observed and varied according to the $U$. brizantha cultivar (Marandu or Piatã), cropping system (monocropping or intercropping) and agricultural year (2010/2011 or 2011/2012). Significant effects of the forage cereal (corn or sorghum) were not observed for any of the parameters measured (Table 3).

The pre-cut height of the forage canopy at the intercropping system (Table 3) was higher $\left(\mathrm{P}=2.765 .10^{-8}\right)$ for the $2011 / 2012$ season than for the 2010/2011 season. Tropical forages are influenced by edaphoclimatic factors (SILVA NETO et al., 2012). However, climatic variables did not vary greatly between the two agricultural years (Table 1), indicating that the differences in the parameters were not caused by climate factors but rather by the improved soil chemical characteristics of the crop-livestock integration systems (BALBINOT JÚNIOR et al., 2009; FRANZLUEBBERS, 2007). 


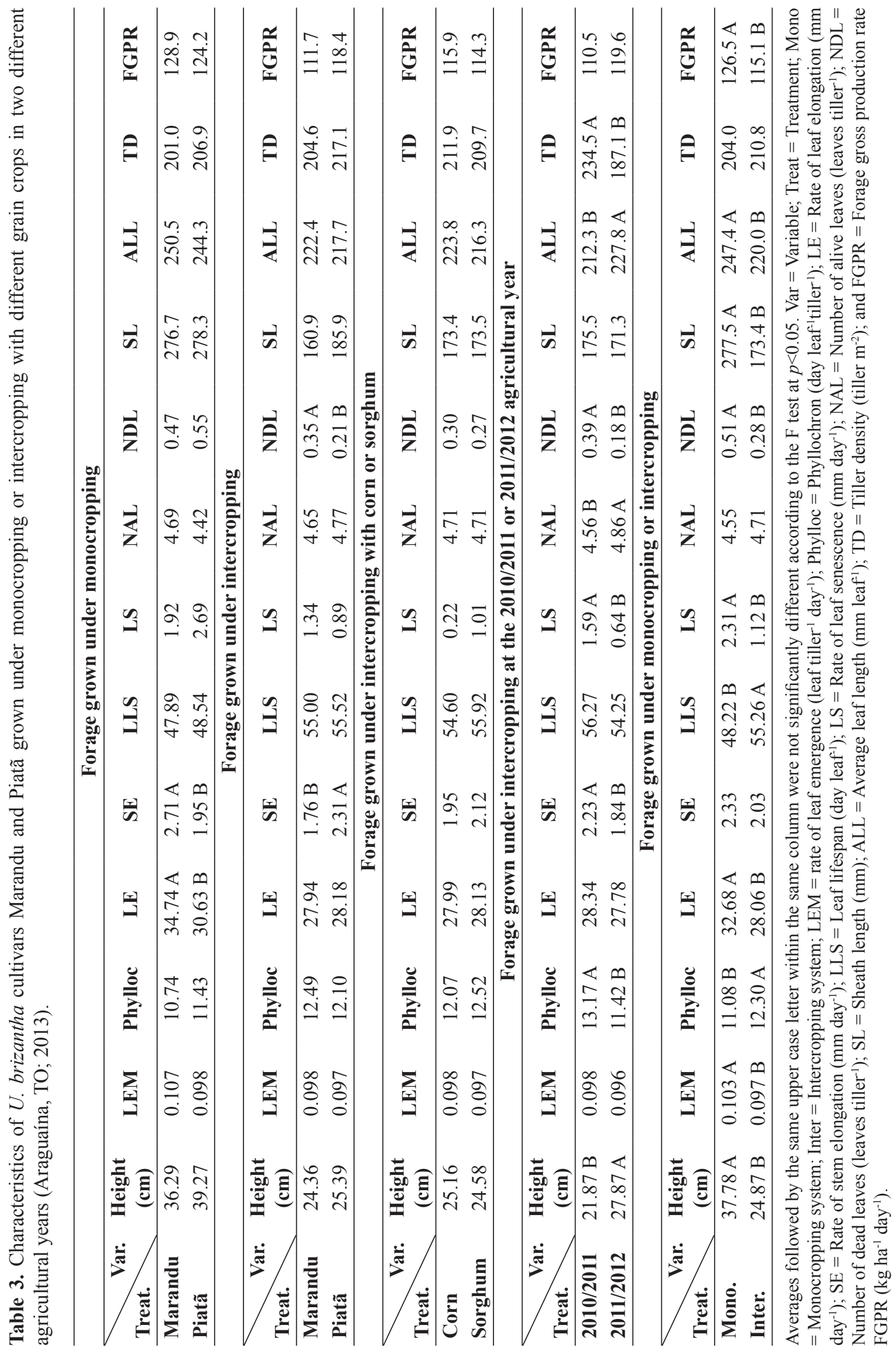


The pre-cut height of the forage canopy was higher for the monocropping systems relative to the intercropping systems $\left(\mathrm{P}=1.695 .10^{-14}\right)$ (Table 3) because the areas where intercropping was established had not yet recovered from the stress of the previously established systems in those areas. The shade provided by cereal forages is a stressor for $U$. brizantha, which has a $\mathrm{C}_{4}$ metabolism. In addition, interspecies competition is maximized in Quartzarenic Neosol soils because higher carbon levels and base concentrations are observed at the soil sorption complex with higher clay concentrations and these soils have a lower water retention capacity (AVELINO et al., 2011; FRAZÃO et al., 2008). In addition, plants originating from intercropping systems allocate a greater proportion of photoassimilates to root recovery and development during the initial cycles, which is detrimental to shoot development (BARDUCCI et al., 2009).

The differences in canopy pre-cut height between the monocropping and intercropping systems was confirmed by the differences in the monocropping system from all of the intercropping systems for both cultivars (Table 4). U. brizantha was influenced similarly by intercropping with corn or sorghum.

LEM was higher under monocropping than under intercropping $(\mathrm{P}=0.032)$ (Table 3$)$. However, this increase was only observed for the Marandu cultivar grown as a monocrop and intercropped with sorghum in the second agricultural year (Table 4). A similar behavior was observed for the phyllochron period (Table 3). However, the lower phyllochron values are more interesting because less time in days is required to achieve LEM, which allows the plant less time for recovery because it will produce more photoassimilates.

The forage growth response, which was indicated by the LEM $(\mathrm{P}=0.032)$ and phyllochron $(\mathrm{P}=$ 0.048 ) values, was improved under monocropping relative to intercropping because of the influence of grain crops on the initial development of the tropical forage grasses, which has been previously discussed.

The LE values were higher for $U$. brizantha $\mathrm{cv}$. Marandu grown under monocropping relative to the remaining monocropping systems $(\mathrm{P}=0.018)$ as well as under monocropping relative to under intercropping, which is consistent with the results for the LEM and phyllochron $\left(\mathrm{P}=2.396 .10^{-5}\right)$ (Table 3). However, significant differences between monocropping and intercropping systems with both grain crops were only observed with the Marandu cultivar (Table 4).

The higher LE observed for monocropping relative to intercropping ( $\left.\mathrm{P}=2.396 .10^{-5}\right)$ (Table 3 ) was caused by higher photoassimilate allocation to promote root recovery and development during the initial cycles of plants grown under intercropping (BARDUCCI et al., 2009). The higher LE is advantageous because LE is related to ALL and dry mass production (SILVEIRA et al., 2010; DIFANTE et al., 2011).

In the monocropping system, the SE was higher for the Marandu cultivar than for the Piatã cultivar $(\mathrm{P}=0.031)$. However, the opposite was observed when the two cultivars were grown under intercropping, with higher values observed for the Piatã cultivar $(\mathrm{P}=0.002)$. The $\mathrm{SE}$ values were also higher for the agricultural year 2010/2011 (P $=0.029$; Table 3 ), although differences were not observed between the Piatã cultivar grown under monocropping or intercropping. However, the Marandu cultivar presented different growth areas when monocropped or intercropped with corn or sorghum in the second agricultural year (Table 4). The response of SE to the different cropping systems may be associated to the greater degree of shading of low leaves and basal buds because of the higher LEM and LE. 
Table 4. Morpho-structural responses of the U. brizantha cultivars Marandu and Piatã grown under monocropping and intercropping in two different agricultural years (Araguaína, TO; 2013).

Continue ...

\begin{tabular}{lcccccc}
\hline \multirow{2}{*}{ Treatment } & \multicolumn{3}{c}{ Height $(\mathbf{c m})$} & \multicolumn{3}{c}{ LEM $_{(\text {leaf tiller }}$ day $^{-1}$ ) } \\
\cline { 2 - 7 } Monocropping Marandu & Averages & Marandu & Piatã & Averages & Marandu & Piatã \\
Monocropping Piatã & 36.29 & $\mathrm{~A}$ & --- & 0.107 & $\mathrm{~A}$ & --- \\
\hline Marandu/Corn/Year I & 39.27 & --- & $\mathrm{A}$ & 0.098 & --- & $\mathrm{A}$ \\
Marandu/Corn/Year II & 23.45 & $\mathrm{~B}$ & $\mathrm{~B}$ & 0.099 & $\mathrm{~A}$ & $\mathrm{~A}$ \\
Marandu/Sorghum/Year I & 26.55 & $\mathrm{~B}$ & $\mathrm{~B}$ & 0.096 & $\mathrm{~A}$ & $\mathrm{~A}$ \\
Marandu/Sorghum/Year II & 27.24 & $\mathrm{~B}$ & $\mathrm{~B}$ & 0.100 & $\mathrm{~A}$ & $\mathrm{~A}$ \\
Piatã/Corn/Year I & 22.35 & $\mathrm{~B}$ & $\mathrm{~B}$ & 0.095 & $\mathrm{~B}$ & $\mathrm{~A}$ \\
Piatã/Corn/Year II & 28.30 & $\mathrm{~B}$ & $\mathrm{~B}$ & 0.096 & $\mathrm{~A}$ & $\mathrm{~A}$ \\
Piatã/Sorghum/Year I & 21.46 & $\mathrm{~B}$ & $\mathrm{~B}$ & 0.099 & $\mathrm{~A}$ & $\mathrm{~A}$ \\
Piatã/Sorghum/Year II & 29.45 & $\mathrm{~B}$ & $\mathrm{~B}$ & 0.096 & $\mathrm{~A}$ & $\mathrm{~A}$ \\
\hline
\end{tabular}

\begin{tabular}{|c|c|c|c|c|c|c|}
\hline \multirow{2}{*}{$\begin{array}{ll}\text { Treatment } & \text { Variable } \\
\end{array}$} & \multicolumn{3}{|c|}{ Phyllochron (day leaf ${ }^{-1}$ tiller $^{-1}$ ) } & \multicolumn{3}{|c|}{ LE (mm day $\left.{ }^{-1}\right)$} \\
\hline & Averages & Marandu & Piatã & Averages & Marandu & Piatã \\
\hline Monocropping Marandu & 10.740 & $\mathrm{~A}$ & --- & 34.739 & $\mathrm{~A}$ & --- \\
\hline Monocropping Piatã & 11.426 & --- & A & 30.630 & --- & A \\
\hline Marandu/Corn/Year I & 13.417 & A & A & 28.135 & B & A \\
\hline Marandu/Corn/Year II & 11.338 & A & A & 27.624 & B & A \\
\hline Marandu/Sorghum/Year I & 13.285 & A & A & 28.672 & B & A \\
\hline Marandu/Sorghum/Year II & 11.922 & A & A & 27.313 & B & A \\
\hline Piatã/Corn/Year I & 12.358 & A & A & 28.214 & B & A \\
\hline Piatã/Corn/Year II & 11.156 & A & A & 27.992 & B & A \\
\hline Piatã/Sorghum/Year I & 13.628 & B & A & 28.333 & B & A \\
\hline Piatã/Sorghum/Year II & 11.266 & A & A & 28.194 & B & A \\
\hline Variable & \multicolumn{3}{|c|}{ SE $\left(m m\right.$ day $\left.^{-1}\right)$} & \multicolumn{3}{|c|}{ LLS (day leaf $\left.{ }^{-1}\right)$} \\
\hline Treatment & Averages & Marandu & Piatã & Averages & Marandu & Piatã \\
\hline Monocropping Marandu & 2.712 & $\mathrm{~A}$ & --- & 47.892 & $\mathrm{~A}$ & --- \\
\hline Monocropping Piatã & 1.955 & --- & A & 48.541 & --- & A \\
\hline Marandu/Corn/Year I & 1.855 & A & $\mathrm{A}$ & 55.555 & $\mathrm{~A}$ & A \\
\hline Marandu/Corn/Year II & 1.502 & B & A & 52.865 & $\mathrm{~A}$ & A \\
\hline Marandu/Sorghum/Year I & 2.247 & A & $\mathrm{A}$ & 57.291 & B & B \\
\hline Marandu/Sorghum/Year II & 1.424 & B & A & 54.286 & A & A \\
\hline Piatã/Corn/Year I & 2.354 & A & A & 54.520 & A & A \\
\hline Piatã/Corn/Year II & 2.096 & A & A & 55.453 & $\mathrm{~A}$ & A \\
\hline Piatã/Sorghum/Year I & 2.446 & A & A & 57.706 & B & B \\
\hline Piatã/Sorghum/Year II & 2.351 & A & A & 54.396 & A & A \\
\hline
\end{tabular}

\begin{tabular}{lcccccc}
\hline \multirow{2}{*}{ Treatment } & \multicolumn{3}{c}{${\text { LS }\left(\mathbf{m m ~ d a y}^{-1}\right)}^{-}$} & \multicolumn{3}{c}{ NAL (leaves tiller-1) } \\
\hline Monocropping Marandu & 1.920 & $\mathrm{~A}$ & --- & 4.687 & $\mathrm{~A}$ & --- \\
Monocropping Piatã & 2.695 & --- & $\mathrm{A}$ & 4.422 & --- & $\mathrm{A}$ \\
\hline Marandu/Corn/Year I & 1.840 & $\mathrm{~A}$ & $\mathrm{~A}$ & 4.484 & $\mathrm{~A}$ & $\mathrm{~A}$ \\
Marandu/Corn/Year II & 1.012 & $\mathrm{~A}$ & $\mathrm{~B}$ & 4.734 & $\mathrm{~A}$ & $\mathrm{~A}$ \\
Marandu/Sorghum/Year I & 1.739 & $\mathrm{~A}$ & $\mathrm{~A}$ & 4.672 & $\mathrm{~A}$ & $\mathrm{~A}$ \\
Marandu/Sorghum/Year II & 0.769 & $\mathrm{~A}$ & $\mathrm{~B}$ & 4.719 & $\mathrm{~A}$ & $\mathrm{~A}$ \\
Piatã/Corn/Year I & 1.582 & $\mathrm{~A}$ & $\mathrm{~A}$ & 4.547 & $\mathrm{~A}$ & $\mathrm{~A}$ \\
Piatã/Corn/Year II & 0.464 & $\mathrm{~A}$ & $\mathrm{~B}$ & 5.078 & $\mathrm{~A}$ & $\mathrm{~B}$ \\
Piatã/Sorghum/Year I & 1.201 & $\mathrm{~A}$ & $\mathrm{~A}$ & 4.547 & $\mathrm{~A}$ & $\mathrm{~A}$ \\
Piatã/Sorghum/Year II & 0.322 & $\mathrm{~B}$ & $\mathrm{~B}$ & 4.922 & $\mathrm{~A}$ & $\mathrm{~B}$ \\
\hline
\end{tabular}




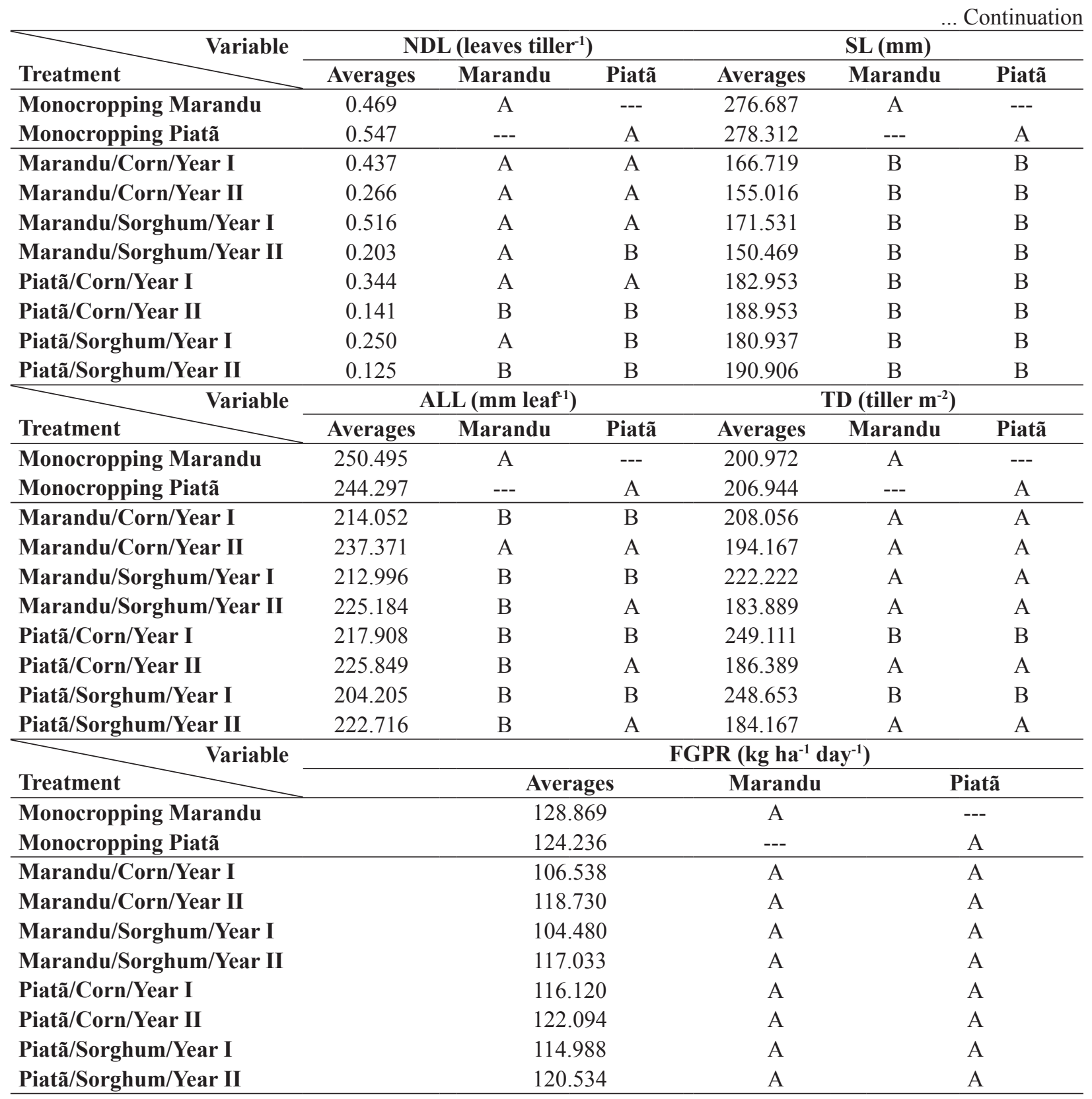

Averages followed by the same upper case letter within the same column and between Marandu cultivars grown under monocropping and intercropping and lower case letters within the same column and between Piatã cultivars grown under monocropping and intercropping were not significantly different according to Dunnett's test at $\mathrm{P}<0.05$. Year $\mathrm{I}=2010 / 2011$ agricultural year; Year II $=$ 2011/2012 agricultural year.

In addition to higher LEM and LE and reduced phyllochron, monocropping systems also presented lower LLS $\left(\mathrm{P}=5.499 .10^{-4}\right)$ and higher LS $(\mathrm{P}=$ 9.324. $10^{-4}$ ) relative to the intercropping systems, indicating an interaction between morphogenic characteristics (Table 3). This result is consistent with previous results showing that grasses tend to present decreased longevity with favorable environments and growth conditions (PACIULLO et al., 2008).

This difference in LS between agricultural years was not observed in the intercropping systems, 
although higher LS was observed for 2010/2011 (P $=0.003$; Table 3 ), which may have been related to the maximization of intercropping effects caused by the lower nutrient input during the 2010/2011 agricultural year compared with the 2011/2012, and these effects may be more pronounced in Quartzarenic Neosol soils. This result also explains the behavior of LS when all of the cropping systems are compared, with lower LS values observed in the intercropping systems in the second agricultural year compared with the first year as well as for the Piatã cultivar growing under monocropping (Table 4).

The NAL value was not affected by the type of cropping system (Table 3 ) because the number of total leaves and live leaves is relatively constant in certain species but can vary with edaphoclimatic conditions (CHAPMAN; LEMAIRE, 1993); this result explains why the NAL of the intercropping systems varied with the agricultural year (Table 3) and why the Piatã cultivar grown under intercropping with both corn and sorghum presented higher NAL compared with its growth under monocropping and why this cultivar's NAL in 2011/2012 was higher relative to that in 2010/2011 (Table 4).

The NDL values presented similar variations to that of LS between different intercropping systems (Table 3). The highest NDL value was observed for the first agricultural year $\left(\mathrm{P}=6.893 .10^{-4}\right)$ and the system using $U$. brizantha $\mathrm{cv}$. Marandu $(\mathrm{P}=$ 0.013 ), and the lowest value was observed for the 2011/2012 agricultural year (Table 4). The highest NDL values were observed for the monocropping system ( $\mathrm{P}=8.378$. 10 $0^{-4}$; Table 3 ). The similarity between LS and NDL was a result of the influence of LS on the amount of dead material (CARNEVALLI et al., 2006).

The results suggest an influence of climatic and anthropic factors (DIFANTE et al., 2011) and indicate that the edaphic environment was improved by the intercropping systems (BALBINOT JÚNIOR et al., 2009; FRANZLUEBBERS, 2007), which affected the morphogenic characteristics of the plants and their interactions with the forage canopy structure. The higher phyllochron resulted in an increase of the time required for the plant to reach the maximum number of leaves and affected the LS and LLS, which consequently influenced the NAL and NDL (Table 3 and 4).

The improved soil chemical characteristics resulting from the inclusion of crop debris from the previous year are related to humified organic matter. Humic substances promote water storage in the soil and increase nutrient supplies for plant growth because they can significantly increase the soil's cation exchange capacity, resulting in higher mineral nutrient reserves (CALONEGO et al., 2012; CANELLAS et al., 2002). In addition, they increase the root surface, which allows the roots to explore a larger soil area and increase the plant's capacity for water and nutrient uptake (CANELLAS et al., 2002, QUAGGIOTTI et al., 2004).

Differences between intercropped $U$. brizantha cultivars were not observed during the first agricultural year because the Piatã cultivar presented higher SL than the Marandu cultivar (Table 5). Differences in SL between agricultural years were only observed for the Marandu cultivar, which presented higher values during the first agricultural year (Table 5). These different SL values for the different cultivars were related to genotypic differences between the cultivars.

The SL values were higher under monocropping systems relative to intercropping systems $(\mathrm{P}=$ 1.355. $10^{-15}$; Table 3 and 4 ), which may have been related to a greater degree of shadowing of low leaves and basal buds because of the higher LEM and LE, which stimulates SE. This result is supported by the SE values and pre-cut height of the forage canopy. 
Table 5. Sheath length (SL) of the Marandu and Piatã cultivars grown under intercropping in two agricultural years (Araguaína, TO; 2013).

\begin{tabular}{|c|c|c|c|c|}
\hline \multicolumn{5}{|c|}{ SL (mm) } \\
\hline Forage $\quad$ Agricultural year & $2010 / 2011$ & 2011/2012 & Average & CV $(\%)$ \\
\hline Marandu & $169.1 \mathrm{Aa}$ & $152.7 \mathrm{Bb}$ & 160.9 & \\
\hline Piatã & $181.9 \mathrm{Aa}$ & $189.9 \mathrm{Aa}$ & 185.9 & 5.29 \\
\hline Average & 175.5 & 171.3 & & \\
\hline
\end{tabular}

Averages followed by the same upper case letter within the same column and lower case letter within the same line were not significantly different according to Tukey's test at $\mathrm{P}<0.05$.

The ALL values in the intercropping systems were higher for the 2011/2012 agricultural year (P $=0.002$; Table 3 ) as well as for the intercropping system with the Piatã cultivar (Table 4). ALL is directly related to SL (DURU; DUCROCQ, 2000) and LE (ALEXANDRINO et al., 2011), which was evident in the comparison of ALL between different cropping systems, with the monocropping systems presenting higher ALL $\left(\mathrm{P}=1.064 .10^{-5}\right)$, SL $\left(\mathrm{P}=1.355 .10^{-15}\right)$ and $\operatorname{LE}\left(\mathrm{P}=2.396 \cdot 10^{-5}\right)$ than the intercropping systems (Table 3 ).

The TD values in the intercropping systems were higher for the 2010/2011 agricultural year ( $\mathrm{P}=$ 0.010 ; Table 3 ) relative to that of the monocropping systems, with the highest tiller densities of the Piatã cultivar observed under intercropping during the first year (Table 4).

The TD results indicate that morphophysiological changes occur in tropical forage grasses as a management strategy under stress conditions, which supports the phenotypic plasticity of these plants (DIAS FILHO, 2011; DIFANTE et al., 2011). Different grasses may therefore present different responses to the same edaphoclimatic or anthropic conditions, and such responses can be observed in the higher TD of intercropped Piatã cultivars for the first agricultural year (Table 4); under the same production conditions, after the removal of the grain crop, this cultivar prioritized increased density subsequent.
The higher tiller density observed for the intercropping system may be related to $U$. brizantha responses to increases in sunlight inside the forage canopy during the initial cycles subsequent to the removal of corn and sorghum. Sunlight promotes the formation of axillary and basal buds, which leads to new tillers (BERNARDINO; GARCIA, 2009). At higher shading levels, the quantity of radiation entering the canopy is decreased, resulting in lower TD. Another factor to be considered is the allocation of photoassimilates to promote root recovery and development and new tiller formation during the initial cycles following the removal of the forage cereal (BARDUCCI et al., 2009).

The FGPR values were higher under monocropping than under intercropping because of the higher LEM rates and larger leaves $(\mathrm{P}=0.046$; Table 3). However, a tendency of the intercropping system to balance this production rate was observed because differences were not observed between the cropping systems (Table 4). The lower FGPR values of the intercropping systems resulted from the allocation of photoassimilates to promote root and new tiller growth during the initial production cycles, although this allocation should be more balanced in subsequent years.

The results indicate that tropical forage grasses are affected by the shading produced by the cereal forages as well as by edaphoclimatic variables. However, these grasses recover quickly following 
the removal of the grain crop, which allows for the establishment of pasture areas. Although intercropping presents lower FGPR values relative to monocropping, the intercropping system is still a viable alternative for the formation of $U$. brizantha pastures. The LER indicated that the intercropping systems were more efficient than the monocropping systems, which would require an increase in area of 30 to $77 \%$ to obtain the same production of intercropping systems (Table 6).

Table 6. Land equivalent ratio (LER) of the intercropping systems over two agricultural years (Araguaína, TO; 2013).

\begin{tabular}{lcc}
\hline & LER & \\
\hline \multicolumn{1}{c}{ Cropping system } & $\mathbf{2 0 1 0 / 2 0 1 1}$ & $\mathbf{2 0 1 1 / 2 0 1 2}$ \\
\hline Marandu + Corn & 1.30 & 1.62 \\
Marandu + Sorghum & 1.39 & 1.34 \\
Piatã + Corn & 1.49 & 1.77 \\
Piatã + Sorghum & 1.46 & 1.43 \\
\hline
\end{tabular}

In the integrative studies, the usual practice of individually evaluating different components of cropping systems should be avoided because the total production per hectare is higher for intercropping than for monocropping systems, even when the production of each component is decreased (SARLAK et al., 2008). The production efficiency of intercropping systems may be evaluated using the LER, with intercropping efficiency indicated by LER values higher than 1 and inefficiency indicated with values lower than 1 (VIEIRA, 1984).

\section{Conclusions}

Intercropping of the $U$. brizantha cultivars Marandu and Piatã with corn or sorghum affected the initial morpho-structural responses of the $U$. brizantha cultivars, and the monocropping system showed higher forage gross production rates.

Intercropping of $U$. brizantha cultivars Marandu and Piatã with corn or sorghum is a viable alternative for restoring degraded pasture areas, and it also provides high production efficiencies.

\section{Acknowledgements}

The authors wish to thank the Centers of Excellence Support Program (Programa de Apoio a Núcleos de Excelência - PRONEX/SECT/ CNPq) (SECT/CNPq Nº8/2010 - PRONEX), the National Network for Research in Agrobiodiversity and Agricultural Sustainability (Redes Nacionais de Pesquisa em Agrobiodiversidade and Sustentabilidade Agropecuária - REPENSA/ $\mathrm{CNPq}$ ) and the Federal Agency for the Support and Evaluation of Graduate Education (Coordenação de Aperfeiçoamento de Pessoal de Nível Superior CAPES) for the Ph.D. scholarship.

\section{References}

ALEXANDRINO, E.; CANDIDO, M. J. D.; GOMIDE, J. A. Fluxo de biomassa e taxa de acúmulo de forragem em capim Mombaça mantido sob diferentes alturas. Revista Brasileira de Saúde e Produção Animal, Salvador, v. 12, n. 1, p. 59-71, 2011.

AVELINO, P. M.; NEIVA, J. N. M.; ARAUJO, V. L.; ALEXANDRINO, E.; SANTOS, A. C.; RESTLE, J. Características agronômicas e estruturais de híbridos de sorgo em função de diferentes densidades de plantio. Revista Ciência Agronômica, Fortaleza, v. 42, n. 2, p. 534-541, 2011. 
BALBINOT JÚNIOR, A. A.; MORAES, A.; VEIGA, M.; PELISSAR, A.; DIECKOW, J. Integração lavourapecuária: intensificação de uso de áreas agrícolas. Ciência Rural, Santa Maria, v. 39, n. 6, p. 1925-1933, 2009.

BARDUCCI, R. S.; COSTA, C.; CRUSCIOL, C. A. C.; BORGHI, E.; PUTAROV, T. C.; SARTI, L. M. N. Produção de Brachiaria brizantha e Panicum maximum com milho e adubação nitrogenada. Revista Archivos de Zootecnia, Córdoba, v. 58, n. 222, p. 211-222, 2009.

BERNARDINO, F. S.; GARCIA, R. Sistemas Silvipastoris. Pesquisa Florestal Brasileira, Colombo, n. 60, p. 77-87, 2009. Edição Especial.

CALONEGO, J. C.; GIL, F. C.; ROCCO, V. F.; SANTOS, E. A. Persistência e liberação de nutrientes da palha de milho, braquiária e labe-labe. Bioscience Journal, Uberlândia, v. 28, n. 5, p. 770-781, 2012.

CANELLAS, L. P.; OLIVARES, F. L.; FAÇANHA, A. L. O.; FAÇANHA, A. R. Humic acids isolated from earthworm compost enhance root elongation, lateral root emergence, and plasma membrane $\mathrm{H}^{+}$-ATPase activity in maize roots. Plant Physiology, Rockville, v. 130, n. 4, p. 1951-1957, 2002.

CARNEVALLI, R. A.; DA SILVA, S. C.; BUENO, A. A. O.; UEBELE, M. C.; BUENO, F. O.; HODGSON, J.; SILVA, G. N.; MORAIS, J. P. G. Herbage production and grazing losses in Panicum maximum cv. Mombaça under four grazing managements. Tropical Grasslands, Brisbane, v. 40, n. 3, p. 165-176, 2006.

CHAPMAN, D. F.; LEMAIRE, G. Morphogenetic and structural determinants of plant regrowth after defoliation. In: BAKER, M. J. (Ed.). Grasslands for our world. Wellington: SIR Publishing, 1993. p. 55-64.

DIAS FILHO, M. B. Os desafios da produção animal em pastagens na fronteira agrícola brasileira. Revista Brasileira de Zootecnia, Viçosa, MG, v. 40, p. 243-252, 2011. Suplemento Especial.

DIFANTE, G. S.; NASCIMENTO JÚNIOR, D.; SILVA, S. C.; EUCliDES, V. P. B.; MONTAGNER, D. B.; SILVEIRA, M. C. T.; PENA, K. S. Características morfogênicas e estruturais do capim-marandu submetido a combinações de alturas e intervalos de corte. Revista Brasileira de Zootecnia, Viçosa, MG, v. 40, n. 5, p. 955963, 2011.

DURU, M.; DUCROCQ, H. Growth and senescence of the successive leaves on a Cocksfoot tiller. Effect of nitrogen and cutting regime. Annals of Botany, Oxford, v. 85, n. 5 , p. $645-653,2000$.

EMPRESA BRASILEIRA DE PESQUISA AGROPECUÁRIA - EMBRAPA. Manual de análises químicas de solos, plantas e fertilizantes. 2. ed. Brasília: Embrapa Comunicação para Transferência de Tecnologia, 2009. $627 \mathrm{p}$.

Sistema brasileiro de classificação de solos. Centro Nacional de Pesquisa de Solos. 3. ed. Brasília: Embrapa, 2013. 353 p.

FRANZLUEBBERS, A. J. Integrated crop-livestock systems in the southeastern USA. Agronomy Journal, Madison, v. 99, n. 2, p. 361-372, 2007.

FRAZÃO, L. A.; PÍCCOLO, M. C.; FEIGL, B. J.; CERRI, C. C.; CERRI, C. E. P. Propriedades químicas de um Neossolo Quartzarênico sob diferentes sistemas de manejo no Cerrado Mato-Grossense. Pesquisa Agropecuária Brasileira, Brasília, v. 43, n. 5, p. 641-648, 2008.

LARA, M. A. S.; PEDREIRA, C. G. S. Respostas morfogênicas e estruturais de dosséis de espécies de Braquiária à intensidade de desfolhação. Pesquisa Agropecuária Brasileira, Brasília, v. 46, n. 7, p. 760-767, 2011.

MACEDO, M. C. M. Integração lavoura e pecuária: o estado da arte e inovações tecnológicas. Revista Brasileira de Zootecnia, Viçosa, MG, v. 38, p. 133-146, 2009. Suplemento Especial.

MOURÃO, M. H. Tocantins trabalha na recuperação de pastagens degradadas para aumentar rebanho bovino. Palmas: Secretaria da Comunicação Social/Governo do Tocantins, 2012. Disponível em: <http://atn.to.gov. br/noticia/2012/2/10/to-trabalha-na-recuperacao-depastagens-degradadas-para-aumentar-rebanho-bovino/> . Acesso em: 12 out. 2013.

PACIULLO, D. S. C.; CAMPOS, N. R.; GOMIDE, C. A. M.; CASTRO, C. R. T.; TAVELA, R. C.; ROSSIELLO, R. O. P. Crescimento de capim-braquiária influenciado pelo grau de sombreamento e pela estação do ano. Pesquisa Agropecuária Brasileira, Brasília, v. 43, n. 7, p. 917-923, 2008.

PARIZ, C. M.; ANDREOTTI, M.; AZENHA, M. V.; BERGAMASCHINE, A. F.; MELLO, L. M. M.; LIMA, R. C. Produtividade de grãos de milho e massa seca de braquiárias em consórcio no sistema de integração lavoura-pecuária. Ciência Rural, Santa Maria, v. 41, n. 5 , p. 875-882, 2011.

QUAGGIOTTI, S.; RUPERTI, B.; PIZZEGHELLO, D.; FRANCIOSO, O.; TUGNOLI, V.; NARDI, S. Effect of low molecular size humic substances on nitrate uptake and expression of genes involved in nitrate transport in maize (Zea mays L.). Journal of Experimental Botany, Oxford, v. 55, n. 398, p. 803-813, 2004. 
RICHART, A.; PASLAUSKI, T.; NOZAKI, M. H.; RODRIGUES, C. M.; FEY, R. Desempenho do milho safrinha e da Brachiaria ruziziensis cv. comum em consórcio. Revista Brasileira de Ciências Agrárias, Recife, v. 5, n. 4, p. 497-502, 2010.

SARLAK, S.; AGHAALIKHANI, M.; ZAND, B. Effect of plant density and mixing ratio on crop yield in sweet corn/mung bean intercropping. Pakistan Journal of Biological Sciences, Faisalabad, v. 11, n. 17, p. 21282133, 2008.

SECRETARIA DE PLANEJAMENTO E DA MODERNIZAÇÃO DA GESTÃO PÚBLICA/ DIRETORIA DE ZONEAMENTO ECOLÓGICOECONÔMICO - SEPLAN/DZE. Estudo da dinâmica da cobertura e uso da terra do Estado do Tocantins. Governo do Tocantins. Palmas: Secretaria do Planejamento/ Governo do Tocantins, 2012. Disponível em: <http:// www.seplan.to.gov.br/Arquivos/download/ZEE/ Dinamica_de_Uso_da_Terra_1990-2007/Din_Cob_ Uso_Tocantins_vol2.pdf $\bar{\top}$. Acesso em: 12 out. 2013.

SILVA, E. T.; CUNHA, J. L. X. L.; MADALENA, J. A. S.; SILVA, J. A. C.; SILVA, W. T. Produção de milho (Zeamays L.) em consórcios com gramíneas forrageiras. Revista Caatinga, Mossoró, v. 21, n. 4, p. 29-34, 2008.
SILVA NETO, S. P.; SANTOS, A. C.; LEITE, R. L. L.; DIM, V. P.; NEVES NETO, D. N.; SILVA, J. E. C. Variação espacial do teor de matéria orgânica do solo e produção de gramínea em pastagens de capim-Marandu. Bioscience Journal, Uberlândia, v. 28, p. 41-53, 2012. Suplemento 1.

SILVEIRA, M. C. T.; NASCIMENTO JÚNIOR, D.; SILVA, S. C.; EUCLIDES, V. P. B.; MONTAGNER, D. B.; SBRISSIA, A. F.; RODRIGUES, C. S.; SOUSA, B. M. L.; PENA, K. S.; VILELA, H. H. Morphogenetic and structural comparative characterization of tropical forage grass cultivars under free growth. Scientia Agricola, Piracicaba, v. 67, n. 2, p. 136-142, 2010.

VIEIRA, C. Índice de equivalência de área. Informe Agropecuário, Belo Horizonte, v. 10, n. 118, p. 12-13, 1984.

YASSIN, N.; MORAIS, A. R.; MUNIZ, J. A. Análise de variância em um experimento fatorial de dois fatores com tratamentos adicionais. Ciência e Agrotecnologia, Lavras, v. 26, n. 6, p. 1541-1547, 2002. 
